TRAINING, WAGE GROWTH AND JOB PERFORMANCE:

EVIDENCE FROM A COMPANY DATABASE

\author{
Ann P. Bartel
}

Working Paper No. 4027

NATIONAL BUREAU OF ECONOMIC RESEARCH 1050 Massachusetts Avenue

Cambridge, MA 02138

March 1992

This paper is part of NBER's research program in Labor Studies. Any opinions expressed are those of the author and not those of the National Bureau of Economic Research. 


\title{
TRAINING, WAGE GROWTH AND JOB PERFORMANCE: EVIDENCE FROM A COMPANY DATABASE
}

\begin{abstract}
This paper studies the relationships between on-the-job training, wages and job performance by using the personnel records of a large manufacturing firm. Utilizing a company database avoids the biases that generally result when individuals are unable to accurately recall the amount of training they received and/or when definitions of training vary across diverse firms.

The main findings presented in this paper are: (1) Controlling for information on days spent in formal training programs reduces the returns to tenure by $18 \%$; (2) First-difference models of wage growth which eliminate heterogeneity bias in wage levels show that training has a positive and significant effect on wage growth; (3) Fixed-effects models that control for heterogeneity bias in wage growth still find a positive and significant effect of training on wage growth; and (4) Training leads to an improvement in job performance, as measured by performance rating scores.
\end{abstract}

Ann P. Bartel

Graduate School of Business Columbia University

710 Uris Hall

New York, NY 10027 and NBER 


\section{INTRODUCTION}

The relationship between on-the-job training and wage growth has been the subject of much research as researchers have sought to determine the validity of the predictions of the theory of human capital. According to this theory, the life-cycle pattern of wages reflects the life-cycle pattern of productivity, which in turn derives from the individual's investments in human capital (Mincer, 1974). Data limitations have typically forced researchers to infer that a relationship exists between human capital investments and productivity by simply studying the shape of wage profiles. The problem with this approach is that it is impossible to refute alternative theories that imply rising wage profiles over the life-cycle but have nothing to do with investments in training.'

Recently, there have been several empirical studies that used actual measures of training (e.g. Barron et.al, 1989; Brown, 1989; Holzer, 1990; Lillard and Tan, 1986; Lynch, 1989; and Mincer, 1988). With the exception of the work by Barron et.al. and Holzer, all of these papers used data on training that was reported by the individual employee, raising questions about the accuracy of an individual's response regarding duration of training. The papers that used the Panel Study of Income Dynamics suffer, in addition, from having to use information on how long it took the "average" person to become qualified for the job, not how long the respondent actually took to become qualified. The paper by Lynch used the NLS Youth Cohort which contains very comprehensive data on private sector training, but, in that dataset,

'For example, Lazear (1981) discusses how firms offer upward-sloping wage profiles to their workers in order to discourage shirking. Salop and Salop (1976) suggest that upward-sloping profiles are used by firms as a way of discouraging "movers" from applying for jobs. Finally, Jovanovic (1979) showed how job-matching under imperfect information could generate upward-sloping wage profiles. 
information on time spent in training is only reported for training spells that are at least four weeks long. The EOPP data used by Barron et.al. and by Holzer are unique in that the data on training were collected from employers but the information on training is only reported for the most recent hire in the sirm.

In this paper, I study the relationship between on-the-job training and wages by using the personnel records of a large manufacturing firm. There are many advantages to using a dataset collected from one firm. First, the problem relating to individuals' recalling the type and amount of training they received is avoided since all training spells are recorded in the individual's personnel record. Second, since the individuals are all trained by the same firm, there is no bias resulting from definitions of training varying across diverse firms. Data of this nature provides the researcher with a unique opportunity to compare the careers of individuals in the same firm and analyze how wage growth within the firm is influenced by training received in that firm. Since the database that I use also contains information on the employees' performance evaluations, I am also able to determine whether training improves an individual's job performance and, if so, whether the performance impact accounts for the positive effect of training on wages. This approach provides a direct test of the human capital theory.

In the next part of the paper, the dataset is described. The econometric framework is discussed in Part III. Results are presented in Part IV. Part V summarizes the analysis and discusses implications for future research. 


\section{DATA}

Data for this study are taken from the 1986-1990 personnel records of a large manufacturing company. The individuals who were classified by the company as professional employees were selected for analysis, resulting in a total sampicic vî i 9,000 observatiōis. averag:ng 3800 individuals per year. These employees are distributed across eight functional areas in the company: (1) Finance, (2) Engineering, (3) Manufacturing, (4) Marketing, (5) Information Systems, (6) R\&D, (7) Staff Services, and (8) Support Services. A sampling of the types of occupations held by these individuals is as follows: accountants, engineers, purchasing agents, quality control planners, market researchers, systems analysts, bench scientists, human resource professionals and industrial hygienists. For each individual who appears in the company's database in a particular year, information is reported on length of service, source of hire, years of education, salary, whether the individual was promoted during the past year, and days spent in training in the past year in several types of training programs. Information on performance ratings is available for the years 1989 and 1990 only.

Table 1 contains summary statistics for the professional employees in the finiiì. This grounjp of iñdividuals is highly educated and well-paid. In 1990, the mean years of schooling was 16.45 and the average monthly salary was $\$ 3700$. The average professional employee was 36 years old, worked for 7 years before coming to this company and had approximately 8.3 years of experience at the company. In 1986, average length of service at the company was higher ( 9.4 years) because the company hired a large number of new professionals during the late 1980s.

The company has a fairly substantial training budget. In 1990, it spent approximately $\$ 1,950$ per employee on formal training. This can be compared to the average figure for all U.S. firms which was approximately 
$\$ 385$ per employee in $1989 .^{2}$ The company offers a wide range of training programs for its professional employees. Table 2 provides a listing of representative course titles in each of three groups of training programs. One group of training programs is called the "Core Program." Courses in this program are designed for wiy individual in the coñuany whose jui iovolves supervising at least one other employee. These courses teach the individual how to evaluate and improve employee performance, how to effectively manage time, how to be an effective leader, and how to implement change. A second group of programs is called "Corporate Employee Development". The courses in this category involve learning such skills as problem solving, decision making, written and oral communication, improving job performance, and time management. Third, the company offers courses in computer skills, information systems, research skills, good manufacturing practices, job safety, and other technical areas. All training programs are offered on a full-day or half-day basis and, as Table 2 shows, typically last between two and five days.

Table 3 provides descriptive statistics on the training received by the professional employees in the firm. For each year, the percentage of employees receiving training, the mean number of days spent in training, and the mean days in training fôr thōse receiving training are shown for three categories of training: (1) "Core" Training, (2) Employee Development, and (3) Other Programs. The last category covers all courses that are not listed in either the core program or the employee development program; for professional employees, this category largely covers research, computer and technical skills. The data in Table 3 show that at least half of the professional employees received some formal training during each of the five years for

${ }^{2}$ See U.S. Congress, Office of Technology Assessment (1990). 
which data are available. On average, these employees spent between two and two-and-one-half days in formal training during the year. For individuals who received some training, the mean days spent in training ranged from 3.3 days to 4.4 days per year. These figures are remarkably close to the numbers reported in the annual survey conducted by Training. Sry few of the professional employees spent time in the "core" training program because the nature of their jobs may not have involved supervisory activities. ${ }^{4}$ Training days split fairly evenly between employee development programs and the other programs.

Since training is more likely to occur during the initial stages of an individual's tenure, the data in Table 3 need to control for length of service at the company. This is done in Table 4 where the probability of receiving training and the days spent in training are calculated separately for each year

${ }^{3}$ Each May, the publishers of Training conduct a survey of American businesses on the amount of time their employees spend in formal training during the year. The surveys for 1989 and 1990 showed that, for individuals who received some formal training, the average amount of time spent in formal training was approximately four days. The company that I am studying appears to be typical of the companies included in Training's nationwide survey.

Data on time spent in formal training in surveys of low-wage workers with high school educations show that these individuals spend more time in formal training. For example, Holzer (1990) shows that, in the EOPP Survey, 10.9 hours was spent by specially trained personnel in providing the most recently hired worker with formal training during the first three months of employment. Assuming that training proceeded at the same rate during the year for those individuals, that would translate into 44 hours or 5.5 days of formal training.

${ }^{4}$ Since the "core" program was introduced at the end of 1986, there were no participants in 1986. 
of hire. In this table, the three training categories are aggregated. Reading across a row in Table 4 shows the "cross-sectional" effect of tenure on the amount of training. In all years except 1987, the probability of receiving training and the number of training days conditional on receipt of training, peaks in tiic second yoi for which an sntry in the table appears, e.g. $71.7 \%$ and 4.4 days for training received in 1990 by individuals hired in 1989 . The reason for this is that individuals are hired during all months of the year. If a hire took place during the latter half of the year, training in the "first" year on the job will not appear until the second calendar year. Although the probability of receiving training and the amount of training are highest for the newly hired employees, experienced employees do receive formal training at this company. For example, in $1990,48.2 \%$ of the individuals who were hired before 1980 received formal training.

The data in Table 4 can also be used to follow a given cohort over time. Starting from the bottom of a column and reading up shows the trend over time in the amount of training received by a group of individuals hired during a given year. Again, the probability of receiving training and the amount of training received tend to be highest during the group's second calendar year at the company. Training does not decline monotonicaily with length of service; in 1989, the company increased its training effort compared to 1987 and 1988, and this produces a spike in the trend for all of the cohorts.

\section{ECONOMETRIC FRAMEWORK}

In order to show the impact of formal training on the wages of the individuals at the company, the analysis begins by estimating the following equation on the pooled cross- 
sectional data set for the time period 1986 through 1990:

$$
\begin{gathered}
\ln (S A L)=\alpha+\beta_{1} Y R S E D+\beta_{2} P R E V+\beta_{3} P R E V S Q+\beta_{4} L O S \\
+\beta_{5} L O S S Q+\beta_{6} S T K T R A I N+\beta_{7} O C C+\beta_{8} Y E A R+\epsilon
\end{gathered}
$$

The dependent variable is the logarithm of the individual's monthly salary measured as of the last day of the calendar year. Years of education (YRSED) is taken directly from the individual's personnel record. Length of service (LOS) at the company is calculated based on information on the date of hire and is measured in years or fractions of years. Previous experience (PREV) is calculated as AGE - YRSED - LOS - 5. A vector of seven occupation dummies (OCC) corresponding to the occupations listed in Table 1 and a vector of year dummy variables (YEAR) are included. The variable STKTRAIN measures the stock of formal training, i.e. the total days of formal training that the individual has received up until time period $t$. Since no information on training received prior to 1986 is reported in the dataset, STKTRAIN can only be accurately measured for individuals hired after 1985 . In the empirical analysis, the three types of training discussed above, CORE, EMPLOYEE DEVELOPMENT, and OTHER, will be analyzed as an aggregate as well as separate categories.

A well-known problem with estimating equations of the type shown in equation (1) is that some of the regressors may be correlated with the error term because of the role of person-specific effects. If, for example, more able or more promising employees receive more training, then the coefficient on STKTRAIN will, at least in part, reflect the role of these unobserved characteristics. This problem can be addressed with this dataset by estimating a first-difference version of equation (1). In particular, annual changes in salary can be regressed on changes in the right-hand variables. In this formulation, all time invariant effects (both observed and unobserved) drop out 
of the equation, leaving only time varying variables. This results in equation (2):

$$
\begin{aligned}
\ln \left(S A L_{t}\right)-\ln \left(S A L_{t-1}\right) & =\beta_{5}\left(S T K T R A I N_{t}-S T K T R A I N_{t-1}\right) \\
& +\gamma \text { PROMOTE }
\end{aligned}
$$

The only time-variant variable that remains from equation (1) is the change in the stock of training days, i.e. the number of training days experienced during the last year. An additional piece of information from the personnel database that can be incorporated into the framework of equation (2) is a dummy variable indicating whether or not a promotion took place during the past year. The company defines a promotion as a move to a new job that carries a higher Hay Point value. In addition to eliminating fixed effects, equation (2) has the advantage of being able to be estimated on the complete sample, not just individuals hired after 1985 .

While the specification in equation (2) is an improvement over equation (1), it still may be plagued by heterogeneity bias if there is heterogeneity in wage growth. If certain employees are on the "fast track" at the company because of some unobserved special characteristic (e.g. drive, ambition, personality) and these individuals receive training as part of their progression up the ranks, then the correction embedded in equation (2) will not eliminate this type of bias. Heterogeneity in wage growth would require reestimating equation (2) with fixed effects, i.e. including a separate intercept for each employee:

$$
\begin{gathered}
\ln \left(S A L_{t}\right)-\ln \left(S A L_{t-1}\right)=\beta_{5}\left(\operatorname{STKTRAIN~}_{t}-S T K T R A I N_{t-1}\right) \\
+\gamma \operatorname{PROMOTE} \lambda_{i}
\end{gathered}
$$


where $\lambda_{i}$ is a vector of individual dummy variables. In equation (3), the coefficients on the regressors measure the effects of deviations of the regressors from their respective employee means on the deviation of percentage wage growth from its employee mean. While inclusion of fixed offouts has thi actrantage of eliminating omitted-variable bias due to unobserved person effects that are constant over time, it has the disadvantage of exacerbating the problem of errors-in-variables (measurement error), generally resulting in parameter estimates and t-statistics that are biased towards zero. ${ }^{5}$

An alternative approach to controlling for unobserved differences in ability is to utilize the company data on performance ratings. For the years in which performance rating data are available, equation (2) can be reestimated to include the individual's performance score:

$$
\begin{gathered}
\ln \left(S A L_{t}\right)-\ln \left(S A L_{t-1}\right)=\beta_{5}\left(\operatorname{STKTRAIN}_{t}-S T K T R A I N_{t-1}\right) \\
+\gamma \text { PROMOTE }+\delta P E R F R A T_{t-1}
\end{gathered}
$$

where PERFRAT $T_{t-1}$ is the individual's performance rating at the end of time period $\mathrm{t}-1$ before training in time period $\mathrm{t}$ takes place. If more able employees are selected to receive training and if the performance ratings accurately measure ability, including this information will reduce the estimated effect of training on wage growth.

Finally, the data on performance ratings can be used to measure the direct impact of training on performance. Since these data are available for two time periods, i.e. 1989 and 1990, equation (2) can be respecified with the dependent variable as the change in performance ratings:

${ }^{5}$ See Griliches and Hausman (1986). 


\section{PERFRAT $_{t}-$ PERFRAT $_{t-1}=$ $\lambda_{1}\left(\operatorname{STKTRAIN~}_{t}-\right.$ STKTRAIN $\left._{t-1}\right)+\lambda_{2}$ PERFRAT $_{t-1}$}

Equation 6.; can only be estimaticu for the sample uf individuals who were in the same job in both time periods. PERFRAT Pi-1 $_{\text {in }}$ included in equation (5) to control for the fact that individuals at the top of the performance scale in time period t-1 can not improve their performance ratings, while those at the bottom can only stay the same or increase their ratings.

IV. Empirical Results

The results of estimating equation (1) are given in Table 5. Column (1) is estimated for the entire sample and does not include any of the training variables. Columns (2) through (6) are restricted to individuals who were hired in 1986 or 1987 . Column (1) shows the standard results for earnings equations: earnings rise with education, previous experience and current experience. Returns to current tenure are larger than the returns to previous experience. In Column (2), when the sample is restricted to new hires, the quadratic term on LOS is eliminated because the maximum length of service is four years. The results show that, for these individuals, earnings rise by $3.6 \%$ per year. Column (3) adds the three variables that measure the stock of training, the total days in training up until the last day of the calendar year under study (i.e. time period t): STKCORE (total days in core training), STKED (total days in employment development training), and STKOTH (total days in other training). Controlling for the stock of training, we find that an additional year of service raises earnings by $3.1 \%$ This amounts to a $14 \%$ reduction in the returns to tenure. Column (3) also shows that days of training in each of the three categories have significant impacts on salary levels. Column (4) does not distinguish the three types of training and the variable 
STKTRAIN is positive and significant; each day of training raises earnings by $.02 \%$. Finally, in columns (5) and (6), length of service is measured in months (LOSM) in order to create greater variation in the tenure variable. Comparing the coefficients on LOSM in the two columns shows that, controlling for the stock of training, reducen ine returns to teriuic ijy $15 \%$.

Table 6 reports the results of estimating the pooled first difference model shown in equation (2). In columns (1) through (5), the regressions are estimated on the complete sample of professional employees. Columns (6) through (9) report the results of estimating equation (2) on the sample of individuals who remained in the same job over the two-year period. Training received during the past year is measured in several ways in this table:

(1) Dummy variables indicating the receipt of training in each of the three categories, CORE, EMPDEV, and OTHER; (2) A dummy variable indicating the receipt of training in any of the three categories, ANYTRN; (3) The number of days in training during the past year in each of the three categories, COREDAYS, EDDAYS, and OTHDAYS; and (4) The number of days in training during the past year in any of the three categories, TOTDAYS. Recall that the specification in equation (2) eliminated length of service as an independent variable under the assumption that the coefficient on length of service did not vary over time. Preliminary analyses indicated that this was an overly restrictive assumption, and, therefore, all of the regressions in Table 6 include LOS as a regressor. ${ }^{6}$

Looking first at the results for all employees, column (1) shows significant effects of the receipt of the three types of training on the annual change in salary. Since the mean salary is $\$ 47,664$, the coefficients shown in

${ }^{6}$ When the regressions were estimated without LOS in the equation, the effect of training was larger and more significant. This is because training is more likely to occur in the early stages of an individual's tenure. 
column (1) translate into a $\$ 476$ increase due to core training, a $\$ 229$ increase due to employee development training, and a $\$ 214$ increase due to other training. These findings can be coupled with information on the costs of training to calculate rates of return on the three types of training. Company documistis show that the per participant direct costs of a day of training, which includes the salaries of the trainers and the costs of materials, room and board, is $\$ 265$. The indirect costs of training can be calculated from data on the salaries of the trainees and the days spent in training in each of the three categories. Direct and indirect costs can then be summed to determine the per participant total costs of training. For example, in 1990, the total cost of training per participant was $\$ 1868$ for the Core Program, $\$ 1356$ for the Employee Development Program, and $\$ 1702$ for Other Programs.

The company's returns from training are the productivity gains that training produces. The magnitude of these productivity gains can be inferred from the wage gain estimates shown in Table 6. A conservative estimate is that the productivity gains equal the wage gains. This assumption is consistent with a company having a value added/wage ratio equal to one. Previous studies have found that productivity increases from training and reduced turnovêi are at least double the wage increases that employees receive.? The latter findings are consistent with a value added/wage ratio that exceeds one, which is in fact the case for the company under study. Using the conservative, lower-bound estimate that productivity gains equal wage gains results, therefore, in a lower-bound estimate of the company's rate of return on employee training. Without adjusting for depreciation and assuming that individuals remain with the company "forever", the rates of return are calculated to be $25 \%$ for Core Programs, $17 \%$ for Employee Development Programs, and $13 \%$ for Other Programs. These rates of return can be 
compared to the rates of return calculated for the PSID data and EOPP data, $29 \%$ and $23 \%$, respectively, as reported in Mincer (1991).

The other results in Table 6 demonstrate the mechanism by which training enhances an individual's career in the company. In column (5), a duiriny variable, PROiviOTE, which equais ule if the inclividual was promoted during the last year, is included in the equation. This reduces the effect of training on wage growth by $35 \%$ for core training, $60 \%$ for employee development training, and $25 \%$ for other training. This occurs because individuals who receive training are significantly more likely to be promoted, ${ }^{8}$ and promotions raise salaries by approximately $\$ 2700$. Individuals who are not promoted either stay in the same job or move to a new job that has the same Hay Point value as the old job (i.e. a lateral move). An important question is whether training benefits individuals who remain in the same job. This is studied in columns (6) through (9). The results show significant effects of all three types of training, but the estimated impacts are smaller than those for the entire sample. Core training raises the salaries of non-job-changers by $\$ 324$, employee development training and other training raise salaries by $\$ 181$ and $\$ 186$, respectively.

The results in Tabie $\sigma$ show that training has a significant effect on the wage growth of employees in the company. As the discussion in Part III indicated, however, these results may be plagued by heterogeneity bias if there is heterogeneity in wage growth. Table 7 reports the results of estimating wage growth equations that control for fixed effects, as described in equation (3). Columns (1) through (3) show that fixed effects estimates of the impact

${ }^{8}$ Binary logit regressions were estimated in which the dependent variable was the probability of being promoted between time period $t-1$ and time period $t$. Individuals who received training during the last year were significantly more likely to be promoted; the t-value on the coefficient on training was 7.1 . 
of training on wage growth remain positive and significant when training is measured as a dummy variable. Rates of return, controlling for fixed effects, are estimated to be $29 \%$ for Core Programs, $8.4 \%$ for Employee Development Programs, and $9.8 \%$ for Other Programs. When training is measured by the number of days in the training proysam, however, only Cure Progralus ilave a positive and significant effect. Hence, the fixed effects results show that an individual's wage growth is significantly increased above what he normally experiences based on his observable and unobservable characteristics, because of his participation in a training program. Above-average days in training do not always increase the individual's wage growth. ${ }^{9}$

The alternative way of controlling for unobserved differences in employee ability is to include the individuals's prior performance rating in the wage growth equation. The personnel records for the years 1989 and 1990 contained the individual's performance rating for that year. The company uses a system of relative performance measures, i.e. an individual is ranked relative to his peers. According to the company's policies, managers are expected to clearly differentiate between employees in order to recognize those whose performance is far superior to that of their peers. For groups of at least 100 employees in the company, managers are expected to follow a targeted distribution of ratings. There are seven levels used in the performance evaluation system. Performance evaluations are done in January of each year; this provides a measure of the individual's "ability" as of the beginning of time period $\mathrm{t}-1$. If better performing employees have higher wage growth, the performance score in $t-1$ should be significant in the wage growth equation. If better performers are also more likely to receive training,

${ }^{9}$ This result may be due to the problem of errors-in-variables discussed in Part III. This problem is more likely to occur when training is measured as days in training rather than a binary variable measuring participation. 
including information on performance ratings will reduce the estimated impact of training on wage growth.

Table 8 contains the results of estimating 1989-1990 wage growth equations. Performance ratings measures are shown as six dummy variables, PERFRAT1 through PERFRAT6, with PERFRAT1 being the highion rating. The excluded category is the seventh, or lowest, level. An additional variable, PRATNEW, is included which is a dummy variable for individuals who are new in their jobs. These employees are unable to receive performance ratings because their supervisors have not had adequate time to evaluate their performance. The coefficients on the performance ratings show that the company rewards the better performers with bigger salary increases. Controlling for performance ratings reduces the estimated impact of only one of the training programs, i.e. the core program. Since the effects of the other two categories of training are not lowered, the aggregate effect of training, as measured by the variable ANYTRN, remains virtually unchanged.

Finally, this dataset provides the unique opportunity to measure the impact of training on job performance. For individuals who did not change jobs between December of 1988 and December of 1990, we have information on their performance ratings at the beginning of 1989 and the beyinuing of 1990. Some of these individuals participated in training programs during calendar year 1989. It is therefore possible to see if individuals who received training also improved their performance rating on the same job. The impact of training on performance ratings can serve as an estimate of the impact of training on true performance. The estimate is likely to be biased downward, however, because the variation in performance scores will be less than the variation in true performance.

Column (1) of Table 9 reports the results of estimating a binary logit equation in which the dependent variable is the probability of receiving a 
higher performance score in 1990 compared to the 1989 score. The independent variables are a dummy variable for receipt of training during 1989 (ANYTRN), length of service, the performance score in 1989, and a vector of occupation dummies. The 1989 performance score is included here because it is impossible fui the rating iu imiprove if the individual is receiving the highest possible rating. ${ }^{10}$ The results show that individuals who received training during 1989 were significantly more likely to receive increases in their performance ratings between 1989 and 1990.

The remaining question is whether the performance effect of training can explain the positive effect of training on wages that has been been observed with this dataset. Column (2) of Table 9 shows that, for the sample of non-job-changers used in column (1), a positive effect of training on wage growth still exists. In column (3), the wage growth equation is re-estimated with the variables PERFIMP (the binary variable indicating a performance improvement between January 1989 and January 1990) and LAGPRAT (the January 1989 performance ratings) added. Two important findings emerge from column (3). First, individuals who improved their performance during the year received bigger wage increases. Second, the performance effect of iraining explains about $20 \%$ of the impact of training on wages. While $20 \%$ may appear to be a small contribution, this estimate is likely to be biased downward because the performance rating scores do not capture the complete variation in performance across individuals.

10 When the lagged performance score variables were coded, the top two performance categories needed to be combined into one category in order for the maximum likelihood algorithm to achieve convergence. For the same reason, length of service needed to be coded in tens of years, rather than years. 


\section{Conclusions}

This paper has contributed to the literature on the role of on-the-job training in explaining wage growth. By using a unique dataset collected from the personnel records of a large company, this paper has avoided many of the measurement problems thai have plagued previuus tesearch on iuis iunic. In particular, the dataset used here circumvents problems relating to individuals' recalling the type and amount of training they received as well as the bias resulting from definitions of training varying across diverse firms.

The analysis in this paper produced several important findings. First, controlling for information on days spent in formal training programs reduces the returns to tenure by approximately $18 \%$. Second, first-difference models of wage growth which eliminate heterogeneity bias in wage levels, showed that training has a positive and significant effect on wage growth which translates into a company rate of return of at least $13 \%$ Third, fixed effects models that control for heterogenity bias in wage growth also found that participation in a training program has a positive and significant effect on wage growth. Finally, utilizing data on performance ratings, this study showed that training leads to an improvement in job performance, thereby confirming a prediction of human capital theory.

This paper has shown that an analysis of training and wages that eliminates the influence of company-specific experiences on employees by studying one company, confirms the findings of previous research that relied on publicly available datasets. The main finding in this paper is that formal training does indeed increase wages, at least in part because it improves job performance. 


\section{References}

Barron et. al. (1989). "Job Matching and On-the-Job Training,," Journal of Labor Economics, Volume 7, Number 1.

Blakemore, Arthur and Dennis Hoffman (1988). "Seniority Ruies and Productivity: An Empirical Test, " mimeo., Arizona State University.

Brown, James N. (1988). "Why Do Wages Increase With Tenure?", American Economic Review, Volume 79, Number 5.

Griliches, Zvi and John Hausman (1986). "Errors in Variables in Panel Data," Joumal of Econometrics, Volume 31, Number 1.

Holzer, Harry (1990). "The Determinants of Employee Productivity And Earnings", Industrial Relations, Volume 29, Number 3.

Jovanovic, Boyan (1979). "Job Matching and the Theory of Turnover," Journal of Political Economy, Volume 87, Number 5.

Lakewood Publications (1990). Training Magazine, October.

Lazear, Edward (1981). "Agency Eamings Profiles, Productivity and Hours Restrictions, " American Economic Review, September.

Lillard, Lee and Hong Tan (1986). "Private Sectur Training: Who Gets It And What Are Its Effects?" Rand Monograph R-3331-DOL/RC.

Lynch, Lisa (1989). "Private Sector Training And Its Impact on the Earnings of Young Workers," NBER Working Paper No. 2872.

Mincer, Jacob (1988). "Job Training, Wage Growth, and Labor Turnover," NBER Working Paper No. 2690.

Salop, Joanne and Steven Salop (1976). "Self-Selection and Turnover in the Labor Market, " Quarterly Journal of Economics.

U.S. Congress, Office of Technology Assessment (1990). Worker Training: Competing in the New International Economy, OTAITE-457 (Washington, D.C.: U.S. Government Printing Office) 
Table 1

Summary Statistics for 1990

\section{Mean Standard Deviation}

Years of Schooling

16.53

2.03

Previous Experience

7.01

6.65

Company Experience

7.41

8.35

Age

35.91

10.09

Monthly Salary

$\$ 3972.83$

949.98

Occupational Distribution

$\begin{array}{ll}\text { Finance } & .048 \\ \text { Engineering } & .141 \\ \text { Manuf. } & .090 \\ \text { Sales } & .078 \\ \text { Info. Systems } & .154 \\ \text { Scientific } & .440 \\ \text { Staff } & .030\end{array}$


Table 2

Representative Course Titles in the Three Training Categories

"CORE" TRAINING PROGRAM

1. Management for Managers

2. Management for Middle Managers

3. Managing and Coaching Performance

4. Leadership Thinking

Length of Course (Days)

5

5

2

3

\section{CORPORATE EMPLOYEE DEVELOPMENT PROGRAM}

1. Oral Presentations Workshop 2

2. Effective Written Communications 3

3. Problem Solving and Decision 4

4. Managing Performance 2

5. Performance Appraisal and 2

Salary Admin.

6. Stress Management 1

7. Time Management 2

\section{OTHER PROGRAMS}

1. Project Management 2

2. Clinical Statistics 3

3. Quality Control 6

4. Good Manufacturing Practices 1

5. Introd. Computer Programming 5 
Table 3

Percent Receiving Training and Mean Days in Various Programs

All "Core" Empl.Devel. Other

$1986(\mathrm{~N}=3235)$

\section{Programs Program Program Programs}

Percent Receiving

Training

Mean Days

Mean Days for Those

in Programs

$1987(\mathrm{~N}=3509)$

Percent Receiving

Training

Mean Days

Mean Days for Those in Programs

$1988(\mathrm{~N}=3900)$

Percent Receiving

Training

Mean Days

Mean Days for Those in Programs

$1989(\mathrm{~N}=4353)$

Percent Receiving

Training

Mean Days

Mean Days for Those in Programs

$1990(\mathrm{~N}=4773)$

Percent Receiving

$$
\text { Training }
$$

Mean Days

Mean Days for Those in Programs

$76.4 \%$

2.5

3.4

$55.3 \%$

1.8

$.1 \%$

.004

$58.5 \%$

1.0

$43.3 \%$

1.5

1.7

3.6

$\begin{array}{llll}3.3 & 4.5 & 2.3 & 3.1\end{array}$

$56.4 \%$

$1.9 \%$

$34.3 \%$

$33.6 \%$

1.9

.08

1.0

0.7

3.3

4.2

2.9

2.1

$29.4 \%$

0.9

3.1

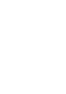

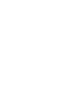


Table 4

Percent Receiving Training And Mean Days For

Those Who Received Training

\section{Year of Hire}

$\begin{array}{llllll}\text { All } & 90 & 89 & 88 & 87 & 86\end{array}$

$\underline{\text { Year }}$

1. $\underline{1990}$

$\%$ Trained

$57.8 \% \quad 56.0 \%$

$71.7 \%$

$67.1 \%$

$63.9 \%$

$62.2 \%$

Mean Days

$3.5 \quad 3.5$

4.4

3.4

3.4

3.3

2. 1989

$\%$ Trained

$63.4 \%-$

$60.1 \% \quad 75.6 \%$

$67.4 \% \quad 66.0 \%$

Mean Days

4.4

3.9

4.9

4.7

4.4

3. $\underline{1988}$

\% Trained

$56.4 \% \quad-$

$58.9 \%$

$68.2 \% \quad 59.9 \%$

Mean Days

3.3

2.9

3.9

3.1

4. 1987

$\%$ Trained

$55.3 \%$

$48.6 \%$

$65.3 \%$

Mean Days

3.3

3.0

4.0

5. 1986

$\%$ Trained

$75.4 \%$

$63.6 \%$

Mean Days

3.4

2.8 
Table 4 (con't)

Percent Receiving Training And Mean Days For

Those Who Received Training

\section{Year of Hire}

$\begin{array}{lllllll}85 & 84 & 83 & 82 & 81 & 80 & \text { Pre-80 }\end{array}$

$\underline{\text { Year }}$

1. $\underline{1990}$

$\begin{array}{llllllll}\text { \% Trained } & 54.1 \% & 53.5 \% & 59.1 \% & 52.9 \% & 48.7 \% & 50.0 \% & 48.2 \%\end{array}$

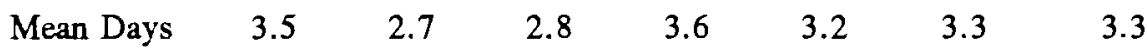

2. 1989

$\begin{array}{llllllll}\text { \% Trained } & 64.5 \% & 65.7 \% & 64.1 \% & 61.5 \% & 60.5 \% & 58.9 \% & 58.6 \%\end{array}$

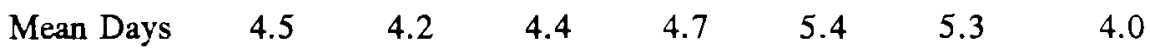

3. 1988

$\begin{array}{llllllll}\text { \% Trained } & 61.7 \% & 61.1 \% & 60.3 \% & 51.8 \% & 55.5 \% & 55.6 \% & 49.4 \%\end{array}$

$\begin{array}{llllllll}\text { Mean Days } & 3.2 & 3.3 & 3.6 & 3.6 & 3.7 & 3.8 & 3.0\end{array}$

4. 1987

$\begin{array}{llllllll}\text { \% Trained } & 61.8 \% & 59.9 \% & 57.2 \% & 54.3 \% & 62.0 \% & 55.1 \% & 52.4 \%\end{array}$

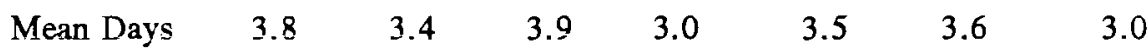

5. 1986

$\begin{array}{llllllll}\text { \% Trained } & 80.4 \% & 77.1 \% & 78.4 \% & 82.4 \% & 78.0 \% & 75.2 \% & 75.2 \%\end{array}$

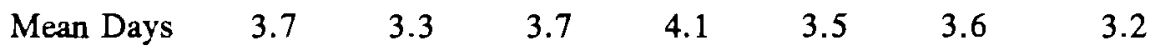


Table 5

Determinants of Ln (Monthly Salary) 1986-1990*

(1)

$\begin{array}{lcccccc} & \underline{\mathrm{b}} & \underline{\mathrm{t}} & \underline{\mathrm{\imath}} & \underline{\mathrm{t}} & \underline{\mathrm{b}} & \underline{\mathrm{t}} \\ \text { YRSED } & .058 & (102.61) & .061 & (40.04) & .061 & (39.78) \\ \text { PREV } & .012 & (29.91) & .018 & (18.19) & .018 & (18.01) \\ \text { PREVSQ } & -.0002 & (-11.99) & -.0003 & (-9.17) & -.0003 & (-8.86) \\ \text { LOSY } & .031 & (90.07) & .036 & (6.93) & .031 & (5.83) \\ \text { LOSSQ } & -.0005 & (-45.81) & & & & \\ \text { LOSM } & & & & & & \\ \text { STKCORE } & & & & & .012 & (3.51) \\ \text { STKED } & & & & & .003 & (3.22) \\ \text { STKOTH } & & & & & .001 & (2.42) \\ \text { STKTRAIN } & & & & & & \\ \text { Y87 } & .042 & (11.64) & .047 & (5.56) & .046 & (5.47) \\ \text { Y88 } & .085 & (23.96) & .091 & (9.33) & .088 & (9.02) \\ \text { Y89 } & .131 & (37.80) & .144 & (10.99) & .137 & (10.52) \\ \text { Y90 } & .177 & (52.02) & .197 & (11.21) & .191 & (10.88) \\ \text { R } 2 & .60 & & .64 & & .64 & \\ \text { N } & 18742 & & 2901 & & 2901 & \end{array}$

* All equations include a vector of occupation dummies. 
Table 5 (con't)

Determinants of Ln (Monthly Salary) 1986-1990*

(4)

$\underline{2}$

YRSED

PREV

PREVSQ

LOSY

LOSSQ

LOSM

STKCORE

STKED

STKOTH

STKTRAIN

Y87

Y88

Y89

Y90

$\mathrm{R}^{2}$

$\mathrm{N}$
.002

.046

.088

.140

.195

.64

2901
(5)

(6)

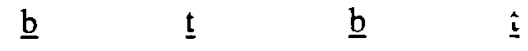

$(40.21)$

(40.42)

.062

(40.54)

(18.19) $\quad .018$

$\begin{array}{ll}(17.79) & .018\end{array}$

(17.86)

$(-8.83) \quad-.0003$

.002

(5.81) $\quad .0017$

(4.41)

(5.79) 
Table 6

Effects of Training on Annual Change in Salary*

All Employees
(1)
(2)
(3)
(4)
(5)

$\begin{array}{ll}\text { CORE } & .0106 \\ & (3.45) \\ \text { EMPDEV } & .0048 \\ & (4.54) \\ \text { OTHER } & .0045 \\ & (4.62)\end{array}$

ANYTRN

.0067

(6.83)

COREDAYS

.0023

.0015

(3.25)

(2.23)

EDDAYS

.0010

.0004

(3.40)

(1.64)

OTHDAYS

.0004

.0003

(1.98)

(1.71)

TOTDAYS

.0007

(4.46)

PROMOTE

LOS

$$
-.001
$$

$-.001$

$-.001$

$-.001$

$-.001$

$(-21.37)$

$(-21.49)$

$(-21.90)$

$(-22.02)$

$(-15.90)$

Constant

$$
.087
$$

.087

.089

.089

.078

(23.94)

(23.81)

(24.68)

(23.65)

$\mathrm{R}^{2}$

.05

.05

.05

.05

.22

$\mathrm{N}$

12226

12226

12226

12226

12226

*All equations include a vector of occupation dummies and a vector of year dummies. $T$-values are given in parentheses. 
Table 6 (con't)

Effects of Training on Annual Change in Salary

Non-Job Changers

(6)

(7)

(8)

(9)

CORE

.0068

(2.05)

EMPDEV

.0038

(3.41)

OTHER

.0039

(3.85)

ANYTRN

.0058

(5.83)

COREDAYS

.0013

(1.71)

EDDAYS

.0008

(2.60)

OTHDAYS

.0003

(1.25)

TOTDAYS

.0005

(2.93)

LOS

$-.001$

$-.001$

$-.001$

$-.001$

$(-14.52)$

$(-14.04)$

$(-14.46)$

$(-14.58)$

Constant

$$
.072
$$

.071

.073

.074

(19.65)

(19.02)

(19.70)

(19.85)

$\mathrm{R}^{2}$

.03

.03

.03

.03

N

9784

9784

9784

9784

*All equations include a vector of occupation dummies and a vector of year dummies. $T$-values are given in parentheses. 
Table 7

Effects of Training on Annual Change in Salary*

(Fixed Effects Estimates)

All Employees
(1)
(2)
(3)
(4)

(5)

$\begin{array}{llll}\text { CORE } & .0114 & & \\ & (2.60) & & \\ \text { EMPDEV } & .0024 & & \\ & (1.67) & & \\ \text { OTHER } & .0035 & & \\ & (2.47) & & \\ \text { ANYTRN } & & .0042 & .0036 \\ & & (3.06) & (2.79)\end{array}$

COREDAYS

.0024

(2.25)

EDDAYS

$-.0001$

$(-.35)$

OTHDAYS

.0002

$(.70)$

TOTDAYS

.0002

PROMOTE

.0512

(34.65)

LOS

.0006
$(1.07)$

.0007

.0004

.0005

0007

(.83)

$\mathrm{R}^{2}$

.38

.38

.47

(1.03)

$\mathrm{N}$

12226

12226

12226

12226

12226

*All equations include a vector of individual employee dummies, a vector of occupation dummies and a vector of year dummies.

$T$-values are given in parentheses. 
Table 8

Effects of Training on 1989-90 Change in Salary, Holding Performance Rating Constant ${ }^{*}$

All Employees

(1)

.013

(2.91)

EMPDEV

.002

(1.09)

OTHER

ANYTRN

LOS

.006

(3.39)
(3)

(4)

(2)

.010

(2.55)

.003

(1.53)

.006

(3.90)

\begin{tabular}{|c|c|c|c|c|c|}
\hline ANYTRN & & $\begin{array}{c}.006 \\
(3.37)\end{array}$ & & $\begin{array}{c}.006 \\
(3.37)\end{array}$ & $\begin{array}{c}.005 \\
(3.11)\end{array}$ \\
\hline LOS & $\begin{array}{c}-.001 \\
(-11.67)\end{array}$ & $\begin{array}{c}-.001 \\
(11.77)\end{array}$ & $\begin{array}{c}-.001 \\
(-11.87)\end{array}$ & $\begin{array}{c}-.001 \\
(-12.01)\end{array}$ & $\begin{array}{c}-.001 \\
(-8.40)\end{array}$ \\
\hline PROMOTE & & & & & $\begin{array}{c}.053 \\
(29.17)\end{array}$ \\
\hline PERFRAT1 & & & $\begin{array}{c}.118 \\
(6.24)\end{array}$ & $\begin{array}{c}.118 \\
(6.26)\end{array}$ & $\begin{array}{c}.098 \\
(5.79)\end{array}$ \\
\hline PERFRAT2 & & & $\begin{array}{c}.093 \\
(4.95)\end{array}$ & $\begin{array}{c}.093 \\
(4.96)\end{array}$ & $\begin{array}{c}.075 \\
(4.50)\end{array}$ \\
\hline PERFRAT3 & & & $\begin{array}{c}.075 \\
(4.04)\end{array}$ & $\begin{array}{c}.076 \\
(4.06)\end{array}$ & $\begin{array}{c}.063 \\
(3.76)\end{array}$ \\
\hline PERFRAT4 & & & $\begin{array}{c}.068 \\
(3.63)\end{array}$ & $\begin{array}{c}.068 \\
(3.66)\end{array}$ & $\begin{array}{c}.058 \\
(3.49)\end{array}$ \\
\hline PERFRAT5 & & & $\begin{array}{c}.058 \\
(3.06)\end{array}$ & $\begin{array}{c}.058 \\
(3.06)\end{array}$ & $\begin{array}{c}.050 \\
(2.95)\end{array}$ \\
\hline PERFRAT6 & & & $\begin{array}{c}.030 \\
(1.52)\end{array}$ & $\begin{array}{c}.030 \\
(1.52)\end{array}$ & $\begin{array}{c}.027 \\
(1.51)\end{array}$ \\
\hline PRATNEW & & & $\begin{array}{c}.060 \\
(3.20)\end{array}$ & $\begin{array}{c}.061 \\
(3.26)\end{array}$ & $\begin{array}{c}.054 \\
(3.25)\end{array}$ \\
\hline
\end{tabular}




$$
\text { Table } 8 \text { (con't) }
$$

Effects of Training on 1989-90 Change in Salary, Holding Performance Rating Constant

\begin{tabular}{ccccc}
\multicolumn{5}{c}{ All Employees } \\
\hline$(1)$ & $(2)$ & $(3)$ & $(4)$ & $(5)$ \\
.097 & .098 & .027 & .027 & .024 \\
$(16.21)$ & $(16.18)$ & $(1.37)$ & $(1.37)$ & $(1.38)$ \\
.05 & .05 & .16 & .16 & .33 \\
3332 & 3332 & 3332 & 3332 & 3332
\end{tabular}

"Dependent variable is $1989-90$ change in salary. All regressions include a vector of occupation dummies. 
Table 8 (con't)

Effects of Training on 1989-90 Change in Salary, Holding Performance Rating Constant ${ }^{*}$

Non-Job Changers

\begin{tabular}{llll}
\hline$(6)$ & $(7)$ & (8)
\end{tabular}

CORE

.006

.003

(1.53)

(.75)

EMPDEV

.000

.001

(.02)

(.62)

OTHER

.005

.005

(3.20)

(3.44)

ANYTRN

(3.73)

(3.55)

LOS

$-.001$

$-.001$

$-.001$

$-.001$

$(-9.11)$

$(-9.11)$

$(-9.48)$

$(-9.40)$

PERFRAT1

$.107 \quad .107$

(7.22)

PERFRAT2

$.079 \quad .080$

(5.46) (5.48)

PERFRAT3

$.063 \quad .064$

(4.37) (4.39)

PERFRAT4

$.057 \quad .057$

(3.94) (3.96)

PERFRAT5

$.049 \quad .049$

(3.37) (3.40)

PERFRAT6

$\begin{array}{ll}.026 & .026 \\ (1.67) & (1.69)\end{array}$

PRATNEW

$\begin{array}{cc}.054 & .055 \\ (3.70) & (3.74)\end{array}$


Table 8 (con't)

Effects of Training on 1989-90 Change in Salary,

Holding Performance Rating Constant

Non-Job Changers

Non-Job Changers

(6) (7) (8) (9)

Constant

$\begin{array}{cccc}.065 & .064 & .006 & .005 \\ (12.01) & (11.75) & (.36) & (.29)\end{array}$

$\mathrm{R}^{2}$

$\begin{array}{cccc}.05 & .05 & .18 & .18 \\ 2586 & 2586 & 2586 & 2586\end{array}$

Dependent variable is $1989-90$ change in salary. All regressions include a vector of occupation dummies. 
Table 9

Impact of Training on Job Performance and Wage Growth for Employees Who Did Not Change Jobs Between 1988 and 1990*

(2)

(3)

Dependent

Variable:

ANYTRN

LOS

PERFIMP

LAGPRAT 1,2

$$
-.601
$$$$
(-11.60)
$$

LAGPRAT 3

$-.142$

$$
(-4.31)
$$

LAGPRAT 5

LAGPRAT 6

$$
\begin{gathered}
.180 \\
(4.01)
\end{gathered}
$$

Constant

.086

(11.18)

1689.48

(307.48)

$$
\chi^{2}
$$

$\mathrm{R}^{2}$

N

1505

1505

$-2 \log \mathrm{L}$

$$
\frac{\operatorname{Jan} 90 \text { SAL }}{\frac{\operatorname{Jan} \varepsilon . S \mathrm{I}}{.0039}}
$$

.0040

(1.80)

.013

.010

$-.016$

$(-4.55)$

$-.017$

$(-2.36)$

.082

(10.81)

rating was better than the 1989 performance rating; it equals zero otherwise. All regressions include a vector of occupation dummies.

Column (1) is estimated via the method of maximum likelihood logit but the coefficients reported are the change in the probability due to a one unit change in the independent variable. LOS is coded in tens of years in column (1). 